\title{
Odnos NOVJ-a prema hrvatskom stanovništvu i poraženim vojnicima oružanih snaga NDH-a u Mostaru krajem Drugoga svjetskoga rata i u neposrednom poraću
}

\author{
Hrvoje MANDić* \\ • https://doi.org/10.31823/d.28.4.2 • \\ UDK: 355.48 (497.6 Mostar) • Izvorni znanstveni rad \\ Primljeno: 27. travnja 2020. Prihvaćeno: 2. prosinca 2020.
}

* Dr. sc. Hrvoje Mandić, Središnji ured za arhivsku građu Sveučilišta u Zagrebu, Ulica kralja Zvonimira 8, 10000 Zagreb, Hrvatska, hrmandic@gmail.com

Sažetak: Zauzimanjem Mostara NOVJ je uspostavio nadzor nad donjim tokom rijeke Neretve i ostvario jedan od dvaju preduvjeta za uspostavu revolucionarne komunisticke vlasti na tom prostoru. Drugi preduvjet bio je obračun sa svim potencijalnim političkim protivnicima, odnosno klasnim neprijateljima u Mostaru. Problematika stradanja hrvatskoga stanovništva u veljači i neposrednom poraću 1945. godine u Mostaru nedovoljno je istražena. Komunističke vlasti svjesno su zanemarivale hrvatske civilne žrtve u veljači i poraću 1945. s pomoću režimske historiografije. Rad predstavlja doprinos istraživanju hrvatskih žrtava u Mostaru. U radu je korištena deskripcija, povijesno-narativna metoda, metoda analize sadržaja, metoda brojenja/nabrajanja i metoda oralne (usmene) povijesti. OZNA i KNOJ počinili su planski, provedbom metode razdavanja i likvidacije, niz ubojstava hrvatskoga stanovništva i pripadnika oružanih snaga NDH-a u Mostaru u veljači te neposrednom poraću 1945. godine. Najveća stratišta pobijenih civila $i$ vojnika nalaze se ispod partizanskoga spomenika u Mostaru, u jami Novakuša prema Nevesinju i lokalitetu Radimlja kod Stoca.

Ključne riječi: Mostar, Josip Broz Tito, oružane snage NDH, NOVJ, OZNA, KNOJ, partizanski spomenik. 


\section{Uvod}

Krajem siječnja 1945. oružane snage Njemačke i NDH-a izvele su vojnu operaciju kodnoga imena Bura na području zapadne Hercegovine. Ta je operacija prouzročila velike gubitke u redovima vlasti Narodnooslobodilačke vojske (NOVJ) na tome području. Vodstvo NOVJ-a, odnosno njezin vrhovni zapovjednik Josip Broz Tito donio je odluku o početku Mostarske operacije, koja je, osim ponovnoga zauzimanja područja koje su u operaciji Bura zauzele oružane snage Njemačke i NDH-a, imala za cilj zauzeti Mostar i Šroki Brijeg. Mostarska je operacija podijeljena u dvije prostorno-vremenske cjeline, pri čemu je prva cjelina bila zauzimanje Širokoga Brijega, a druga zauzimanje Mostara. Postrojbe NOVJ-a zauzele su Široki Brijeg 7. veljače 1945. godine. ${ }^{1}$ Dva dana nakon završetka borbi za Široki Brijeg, 9. veljače, u Čitluku je održan sastanak načelnika Štaba VIII. dalmatinskoga korpusa te zapovjednika 29. hercegovačke i 19. dalmatinske divizije. Na sastanku je zaključeno da u predstojećem dijelu operacije u sastav 19. dalmatinske divizije uđe 12. hercegovačka brigada. ${ }^{2} \mathrm{U}$ borbama za Mostar sudjelovala je 5. brigada 1. hrvatske divizije KNOJ-a. Njezine dvije bojne, 1. i 3., sudjelovale su u borbama za Mostar. U samom gradu djelovali su naoružani pripadnici partizanskoga pokreta koji su surađivali s pripadnicima OZNA-e u Mostaru i pripadnici organizacije Mladi muslimani koji su boravili na području Donje Mahale. ${ }^{3}$

Problematika stradanja hrvatskoga stanovništva u veljači i neposrednom poraću 1945. u Mostaru nedovoljno je istražena. Spomenica Mostara 1941. - 1945. ${ }^{4}$, objavljena 1987. godine, rađena je za potrebe komunističkoga režima. Među najpoznatijim autorima toga režimskoga žrtvoslova jest povjesničar Karlo Drago Miletić. ${ }^{5}$ Spomenica obiluje faktografskim pogrješkama, krivotvorinama i ima izrazito ideološki okvir, a najveći nedostatak Spomenice jest taj što su zanemarene žrtve civil-

${ }^{1}$ L. SUBOTIĆ, Kninska i mostarska operacija, Beograd, 1962., 60.

${ }^{2}$ D. GRGUREVIĆ, Devetnaesta sjevernodalmatinska divizija, Zagreb, 1964., 189.

${ }^{3}$ Bosna i Hercegovina (dalje: BiH), Pismohrana Vicepostulature postupka mučeništva Fra Leo Petrović (dalje: PVPMLP), Iskaz Karla Drage Miletića u Mostaru (dalje: BIH-PVPMLP-IKDM), Mostar, 31. ožujka 2009., 70-85.

${ }^{4}$ G. ULJAREVIĆ, N. MILIVOJEVIĆ, R. HAMZIĆ, K. D. MILETIĆ, B. BUHA, Spomenica Mostara 1941. - 1945., Mostar, 1987.

${ }^{5}$ Karlo Drago Miletić napisao je nekoliko studija o Hercegovini za vrijeme Drugoga svjetskoga rata. U časopisu Hercegovina obradio je u kraćim crtama događaje u Hercegovini u travnju 1941. godine, kao i ponovnu uspostavu talijanske vlasti u članku Talijanska reokupacija Mostara rujan 1941. do lipnja 1943. Navedeni autor objavio je članak Stradanje u Mostaru u zborniku radova Hercegovina u Narodnooslobodilačkoj borbi april 1941. - juni 1942. Članak donosi pregled zločina prema Srbima i Židovima koje su počinile njemačke snage i vlasti NDH-a na području Mostara u Drugom svjetskom ratu. Miletić je autor više knjiga, znanstvenih članaka i rasprava o povijesti grada Mostara. 
noga stanovništva nastale tijekom partizanskoga osvajanja Mostara u veljači 1945., a o čemu će riječ biti u kasnijim poglavljima. Za navedenu temu važna je i monografija naziva Metastaze jedne revolucije. Uspostava komunističko-partizanske vlasti u zapadnim dijelovima Hercegovine (listopad 1944. - ožujak 1945.) u kojoj autor piše o uspostavi komunističke vlasti od jeseni 1944. do zime 1945. godine. ${ }^{6}$ Navedena monografija nezaobilazna je za tu tematiku zbog istraživanja civilnih žrtava grada Mostara.

Za opseg stradanja hrvatskoga naroda u Bosni i Hercegovini u Drugom svjetskom ratu i poraću, kao i za samu temu ovoga članka, korisni su žrtvoslovi pojedinih mjesta. Prema podatcima Povjerenstva za obilježavanje i uređivanje grobišta iz Drugog svjetskog rata i poraća iz Širokog Brijega, utvrđeno je 379 groblja i stratišta, a od toga je 161 službeno obrađeno te zabilježeno u formularima toga povjerenstva. ${ }^{7}$ Arheolog Stanislav Vukorep istraživao je opseg stradanja Hrvata u istočnoj Hercegovini u Drugom svjetskom ratu i poraću. Njegovo djelo Stradanje Hrvata tijekom Drugog svjetskog rata i poraća u istočnoj Hercegovini korisno je za tu znanstvenu problematiku. ${ }^{8}$ Prema tim istraživanjima tijekom Drugoga svjetskoga rata ubijena je 2551 osoba, a u neposrednom poraću još 1864 osobe. Od toga broja 2138 osoba bili su civili (od čega 684 djece do 15 godina i 817 žena stradalih tijekom rata), a 2277 vojnici koji su poginuli u borbama ili su zarobljeni te ubijeni u neposrednom poraću 1945. godine. ${ }^{9}$

Najveći nedostatak za istraživanje te tematike jest manjak arhivskih izvora u Arhivu Hercegovačko-neretvanske županije (dalje: AHNŽ) i Arhivu Provincije u Mostaru (dalje: AP). Za potrebe ovoga istraživanja manji dio izvorne ratne građe nalazi se u Republici Hrvatskoj u Hrvatskom državnom arhivu u Zagrebu, u arhivskim fondovima: Zbirka mikrofilmova, Narodnooslobodilačka vojska (NOV) i partizanski odredi (PO) Hrvatske, VIII. dalmatinski korpus, fond D-181, D-182, D-183, D-1185, D-1186 (signatura fonda HR-HDA-D-181). Vrlo vrijedan arhivski fond za ovu tematiku jest Zbirka preslika fra Krunoslava Draganovića. ${ }^{10}$ Dio građe nalazi se u Državnom arhivu u Splitu, u arhivskom fondu: HR-HDAST-1912-XXVI. dal-

\footnotetext{
${ }^{6}$ I. ŠARAC, Metastaza jedne revolucije. Uspostava komunističko-partizanske vlasti u zapadnim dijelovima Hercegovine (listopad 1944. - ožujak 1945.), Mostar, 2019.

${ }^{7}$ SKUPINA AUTORA, Otkopana istina Širokog Brijega iz II. svjetskog rata i poraća. U spomen ratnim i poratnim žrtvama Širokog Brijega 1941. - 1953., Široki Brijeg, 2017., 537-578.

${ }^{8}$ S. VUKOREP, Stradanja Hrvata tijekom Drugog svjetskog rata i poraća u istočnoj Hercegovini, u: I. PULJIĆ, ISTI (ur.), Humski zbornik, V, Zagreb, 2001.

${ }^{9}$ Isto, 86.

${ }^{10}$ Hrvatska (dalje: HR), Hrvatski državni arhiv (dalje: HDA), Zbirka preslika Krunoslava Draganovića (dalje: HR-HDA-1805-ZPKD), ukupno: 6 kutija.
} 
matinska divizija. Značajno arhivsko gradivo, otpremljeno iz Republike Hrvatske u vrijeme naglašenoga centralizma u bivšoj Jugoslaviji, nalazi se u Beogradu u Arhivu Jugoslavije, $\mathrm{u}$ arhivima Ministarstva vanjskih poslova i Vojnom arhivu. ${ }^{11} \mathrm{U}$ fondovima Vojnoga arhiva u Beogradu (VAB) nalazi se fond NOVJ 1941. - 1945. Za ovo istraživanje također ćemo se koristiti Pismohranom Vicepostulature postupka mučeništva Fra Leo Petrović i 65 subraće. ${ }^{12}$

\section{Borbe za Mostar od 13. do 15. veljače $1945 .{ }^{13}$}

Štab 19. dalmatinske divizije naredio je 12. veljače napad u smjeru Jastrebinka Hum - Mostar. Zbog snježne oluje toga dana napad je odgođen za 13. veljače. Opći napad glavnine postrojbi 26. dalmatinske divizije počeo je 13 . veljače u 7 sati topovskom paljbom po njemačkim obrambenim položajima na Mikuljači i k. $901 .{ }^{14}$ Toga istoga dana oko 10 sati postrojbe 3. dalmatinske prekomorske brigade i 12 . dalmatinske brigade osvojile su Crni Vrh i Jastrebinku. ${ }^{15}$ Postrojbe 11. dalmatinske brigade naišle su na snažan otpor postrojbi NDH-a i njemačke vojske na Mikuljači i Keveljavači toga dana, no uz potporu 12. dalmatinske brigade i tenkova partizani

${ }^{11}$ Istraživanje u tim arhivima zahtijeva putne troškove, troškove boravka i ostala naprezanja u situaciji kad se istražuje s ograničenim vremenom boravka. Jedan od najtežih i najskupljih istraživačkih pothvata jest onaj u Vojnom arhivu u Beogradu. Razlog je taj što su potrebne posebne dozvole koje se rješavaju na razini ministarstava vanjskih poslova dviju zemalja. Uz to, potrebno je odobrenje za rad na određenoj istraživačkoj tematici u samome arhivu. Ako se dobije odobrenje za temu, često je ograničeno količinom izdane građe, dopuštenom količinom i cijenom fotokopiranih dokumenata i udaljenosti od središta Beograda. Vojni arhiv sadrži fond Nezavisne Države Hrvatske 1941. - 1945. godine. Fond je jedan od najvećih u Vojnom arhivu. Sadrži 555 arhivskih jedinica u više od 330 kutija, a još je uvijek nepoznata količina nepopisane građe. Taj nepopisani dio do prije nekoliko godina bio je u podrumu te institucije, uredno složen, ali izvan upotrebe za istraživače jer dokumenti nisu bili arhivski obrađeni. Z. DESPOT, Što sadrži fond Nezavisne Države Hrvatske u beogradskome Vojnom arhivu. Dostupno na: https://blog.vecernji.hr/zvonimir-despot/sto-sadrzi-fond-nezavisne-drzavehrvatske-u-beogradskome-vojnom-arhivu-1061 - blog.vecernji.hr (11.3. 2019.).

${ }^{12}$ Riječ je o svjedočenjima koja su dana na korištenje za postupak proglašenja mučenika. U radu će se koristiti inicijalima svjedoka kako bi se zaštitila njihova tajnost. Svi svjedoci poznati su autoru teksta.

${ }^{13}$ Poglavlje $\gg$ Borbe za Mostar u veljači 1945.« objavio sam u svojoj doktorskoj disertaciji. H. MANDIĆ, Hercegovačka franjevačka provincija u Drugom svjetskom ratu i poraću, Sveučilište u Zagrebu, 2020., 335-337. Zatim, prošireno poglavlje »Borbe za Mostar u veljači 1945 « dostupno je na: https://kamenjar.com/hrvoje-mandic-likvidacija-franjavaca-u-borbama-za-mostar-u-veljaci1945-godine/?cv=1 (30.4.2020.).

${ }^{14}$ HR-HDA-D1182, Narodnooslobodilačka vojska i partizanski odredi Hrvatske (dalje: HR-HDAD1182-NOV i PO Hrvatske, VIII. dalmatinski korpus, rola br. 9, sn. 207. Usp. B. MATKOVIĆ, Zločini postrojba VIII. dalmatinskog korpusa NOVJ-a u Hercegovini početkom 1945. godine, u: Hum: časopis Filozofskog fakulteta Sveučilišta u Mostaru 7(2011.)7, 323.

${ }^{15}$ L. SUBOTIĆ, Kninska i mostarska operacija, 61. 
su zauzeli te položaje uvečer 13 . veljače. ${ }^{16}$ Dijelovi 12 . hercegovačke brigade zajedno s postrojbama 6 . dalmatinske brigade oko podnevnih sati 14 . veljače ovladali su položajem Varda i k. $622 .{ }^{17}$

Do poslijepodnevnih sati 14. veljače postrojbe VIII. dalmatinskoga korpusa razbili su obrambene položaje postrojbi NDH-a i njemačke vojske oko grada Mostara. Postrojbe 26. dalmatinske divizije uz podršku oklopa oko 13 sati ušle su u grad sa zapadne i sjeverozapadne strane. Nijemci su se povlačili upravo na južnom bojištu Mostara iz smjera sela Jasenice - Varda prema Mostaru, a 12. hercegovačka brigada pritiskala je njemačke postrojbe $\mathrm{u}$ smjeru Rodoča radi osvajanja zrakoplovnoga uzletišta. ${ }^{18}$ Postrojbe 1., 11. i 12. dalmatinske brigade uz podršku oklopa zauzele su sve mostove na rijeci Neretvi do 15 sati. Veći dio 12. dalmatinske brigade uz pomoć tenkova i manjega dijela 1. dalmatinske proleterske brigade nakon prelaska preko mosta i osvajanja hotela Neretva krenule su desno prema brdu Humu (k. 436), južno od Mostara. ${ }^{19}$ Nakon osvajanja Huma u južni dio grada ušle su postrojbe 19. dalmatinske divizije, 6 . dalmatinske brigade, 14 . dalmatinske brigade i 12 . hercegovačka brigada te naposljetku 29. hercegovačka divizija, njezina 13 . brigada. ${ }^{20}$ Dio postrojbi 12 . hercegovačke brigade prvi je ušao u Donju Mahalu, na južnoj strani Mostara. ${ }^{21}$

${ }^{16}$ M. RAKO, Jedanaesta dalmatinska u mostarskoj operaciji, u: F. TRGO (ur.), Mostarska operacija - učesnici govore, Beograd, 1986., 259-260. Usp. B. MATKOVIĆ, Zločini postrojba VIII. dalmatinskog korpusa NOVJ-a u Hercegovini početkom 1945. godine, 322. Usp. L. SUBOTIĆ, Kninska i mostarska operacija, 61.

${ }^{17}$ D. DAMJANOVIĆ, Borbe 6. brigade oko Varde i prodor u Mostar, u: F. TRGO (ur.), Mostarska operacija - učesnici govore, 212. Usp. D. GRGUREVIĆ, Devetnaesta sjevernodalmatinska divizija, 191.

${ }^{18}$ HR-HDA-D1182-NOV i PO Hrvatske, VIII. dalmatinski korpus, rola br. 9, sn. 207.

${ }^{19}$ N. ANIĆ, Dvanaesta dalmatinska divizija u mostarskoj operaciji, u: F. TRGO (ur.), Mostarska operacija - učesnici govore, 279.

${ }^{20}$ A. T. BIOČIĆ, Mostarska operacija, u: F. TRGO (ur.), Mostarska operacija - učesnici govore, 123. Vidi izvješća: Hrvatska (dalje: HR), Hrvatski državni arhiv Split (dalje: HDAST), HR-HDAST-1912XXVI. dalmatinska divizija, V. brigada narodne obrane I. hrvatske divizije KNOJ-a, Operativni dnevnik 2. bataljuna KNOJ-a, kutija 7. Original u Vojno-istorijskom institutu JNA, reg. 1-27/13, br. 1101 , HR-HDAST-1912-XXVI. dalmatinska divizija, V. brigada narodne obrane I. hrvatske divizije KNOJa, Operativni dnevnik 3. bataljuna KNOJ-a, original u Vojno-istorijskom institutu JNA, reg. 1-21/14, br. 1101., kutija 7., 72., HR-HDAST-1912-XXVI. dalmatinska divizija, V. brigada narodne obrane I. hrvatske divizije KNOJ-a, Operativni dnevnik 3. bataljuna KNOJ-a, original u Vojno-istorijskom institutu JNA, reg. 1-21/14, br. 1101., kutija 7., 72., HR-HDAST-1912-XXVI. dalmatinska divizija, V. brigada narodne obrane I. hrvatske divizije KNOJ-a, Operativni dnevnik 3. bataljuna KNOJ-a, original u Vojno-istorijskom institutu JNA, reg. 1-21/14, br. 1101., kutija 7., 73. i HR-HDAST-1912XXVI. dalmatinska divizija, Predmet izvješća 3. bojne 11. dalmatinske brigade u napadu na Mostar 12. ožujka 1945., original u Vojno-istorijskom institutu JNA, reg. br. 4-11, k. 1101., kutija 7., 1-2. U zaključnom dijelu izvješća navodi se kako je likvidirano 30 neprijateljskih vojnika, zarobljeno 33, a ranjeno 10. Dok za vlastite gubitke tvrde da su izgubili 3 vojnika, a ranjeno je 27.

${ }^{21}$ O. ĐIKIĆ, Dvanaesta hercegovačka NOU brigada, Beograd, 1990., 174. 
Osim svih tih postrojbi u borbi za Mostar sudjelovale su specijalne postrojbe 1 . hrvatske divizije KNOJ-a i pripadnici 3. brigade bosanskohercegovačke divizije KNOJ-a. Postrojba 1. bataljuna 3. bosanskohercegovačke brigade KNOJ-a u borbama za Mostar imala je zadatak odmah po osvajanju grada preuzeti osiguranje mostova, važnih objekata, ustanova, otkrivanja i pokolja političkih neistomišljenika koje su označili $\gg$ suradnicima fašističkim i ustaškim zločincima «. ${ }^{22}$

Postrojbe 1. tenkovske brigade, postrojbe 12. brigade i 1. dalmatinske proleterske brigade prešle su Most kralja Petra Karađorđevića (danas Most Musala) 14. veljače $\mathrm{i}$ ušle $\mathrm{u}$ istočni dio grada, a $\mathrm{u}$ kasnim večernjim satima toga istoga dana dio postrojbi 11. dalmatinske brigade prešao je Stari most i izbio u istočni dio grada Mostara. ${ }^{23}$ Prema dosadašnjim tumačenjima jugoslavenska historiografija navodi kako je glavnina snaga VIII. dalmatinskoga korpusa zauzela Mostar u 19 sati 14 . veljače. ${ }^{24} \mathrm{Me}-$ đutim postrojbe NOVJ-a u potpunosti su ovladale Mostarom sutradan, 15. veljače. U jednom izvješću iz veljače 1945. Štabu VIII. dalmatinskoga korpusa Glavnom štabu NOVJ-a Hrvatske komandant VIII. dalmatinskoga korpusa Petar Drapšin napisao je sljedeće:

»Danas 15. februara u 6 sati ujutro potpuno smo oslobodili oblasno središte i važni strateški centar grad Mostar. Šaljemo Vam pozdrav iz oslobođenog Mostara. $\ll^{25}$ Partizani su spriječili rušenje mostova preko Neretve u Mostaru, koje su pripadnici mostarske posade minirali kako bi usporili napredovanje partizanskih snaga. Među ostalim, probojem vanjskih obrambenih obruča Mostara raspala se domobranska komponenta u sastavu oružanih snaga $\mathrm{NDH}-\mathrm{a}$, a njemačkim vojnicima prepuštena je obrana Mostara. ${ }^{26}$

${ }^{22}$ J. ANDRIĆ, Jedinica 3. brigade narodne odbrane u mostarskoj operaciji, u: F. TRGO (ur.), Mostarska operacija - učesnici govore, 397-398.

${ }^{23}$ N. ANIĆ, Dvadeset šesta dalmatinska divizija u mostarskoj operaciji, u: F. TRGO (ur.), Mostarska operacija - učesnici govore, 234., Usp. B. MATKOVIĆ, Zločini postrojba VIII. dalmatinskog korpusa NOVJ-a u Hercegovini početkom 1945. godine, 322-323.

${ }^{24}$ D. KOMNENOVIĆ, M. KRESO, Dvadeset deveta divizija u mostarskoj operaciji, u: F. TRGO (ur.), Mostarska operacija - učesnici govore, 319., Usp. L. SUBOTIĆ, Kninska i mostarska operacija, 64.

${ }^{25}$ HR-HDA-D-1182, NOV i PO Hrvatske VIII. dalmatinski korpus, rola br. 9, sn. 207. Svjedok K. D. M. navodi oznaku Vojno istorijskog instituta u Beogradu, Arhiv VII. k. 119/8. reg. br. 1-2. BIHPVPMLPŠB-IKDM, Mostar, 31. ožujka 2009., 70.

${ }^{26}$ Nakon operacije Bura i nakon borbi za Široki Brijeg postrojbe NDH-a pretrpjele su velike gubitke u ljudstvu i vojnoj opremi, te se nisu bile u stanju nositi s NOVJ-em u borbi za Mostar. F. SCHRAML, Hrvatsko ratište, Zaprešić, 1993., 106. Usp. N. ŽIVKOVIĆ, Srbi u ratnom dnevniku Vermahta, Beograd, 2003., 64. 


\section{POSLJEDICE BORBI ZA MOSTAR}

Prema istraživanju Vladimira Šumanovića jugoslavenska historiografija u neautentičnom dokumentu naziva Izvještaj Štaba VIII. korpusa NOVJ od 25. veljače 1945. Vrhovnom Štabu NOV i POJ o oslobođenju Zapadne Hercegovine i Mostara navodi kako su u borbama za Mostar pripadnici NOVJ-a nanijeli gubitke oružanim snagama Njemačke i NDH-a u visini od 3716 poginulih i 1044 zarobljena vojnika. Brojkom su se uzastopno koristili u jugoslavenskoj historiografiji i publicistici, gdje su se autori pozivali na navedeno izvješće od 25. veljače upućeno Generalštabu JA-a o Mostarskoj operaciji, a koje je neautentično. ${ }^{27}$ Prema drugom izvoru, u borbama za Mostar njemačke i oružane snage $\mathrm{NDH}$-a pretrpjele su gubitke od 5778 poginulih i 1314 zarobljenih vojnika. ${ }^{28}$ Prema ratnoj dokumentaciji VIII. dalmatinskoga korpusa ističe se kako su u borbama za Mostar oružane snage Njemačke i NDH-a imale gubitke oko 2000 mrtvih i 1200 zarobljenih vojnika. ${ }^{29}$ To izvješće čini se mnogo vjerodostojnije nego izvješće od 25 . veljače upućeno Generalštabu JA-a. Partizanski gubitci ukupno, s postrojbama VIII. dalmatinskoga korpusa i 29. hercegovačke divizije, iznose 536 poginulih i 1544 ranjena vojnika. ${ }^{30}$ Ti podatci ne mogu se uzeti sa sigurnošću jer se temelje na neautentičnom izvješću Štaba VIII. dalmatinskoga korpusa od 25. veljače upućenom Generalštabu Jugoslavenske armije (JA). ${ }^{31}$

$S$ druge strane nije moguće utvrditi točan broj poginulih pripadnika njemačkih i oružanih snaga NDH-a jer nije moguć cjelovit uvid u dokumentaciju njemačkih postrojbi 369. pješačke divizije i oružanih snaga NDH-a. ${ }^{32} \mathrm{Kad}$ se govori o navedenoj njemačkoj dokumentaciji, operativna izvješća, logistika, vojni zemljovidi 369.

\footnotetext{
${ }^{27}$ Pitanje neautentičnosti izvješća obradio je V. ŠUMANOVIĆ, Pitanje autentičnosti izvješća VIII. dalmatinskog korpusa Generalštabu Jugoslavenske armije od 25. veljače 1945. o Mostarskoj operaciji, u: Časopis za suvremenu povijest 50(2018.)1, 143-160.

${ }^{28}$ N. ANIĆ, Antifašistička Hrvatska. Narodnooslobodilačka vojska i partizanski odredi Hrvatske 1941. - 1945., Zagreb, 2005., 237. Neki podatci govore o 515 poginulih, 1600 ranjenih i 330 nestalih partizana.

${ }^{29}$ HR-HDA-D1182-NOV i PO Hrvatske VIII. dalmatinski korpus, rola br. 9, sn. 213.

${ }^{30}$ F. TRGO, Osnovni podaci o mostarskoj operaciji, u: F. TRGO (ur.), Mostarska operacija - učesnici govore, 23.

${ }^{31}$ V. ŠUMANOVIĆ, Pitanje autentičnosti izvješća VIII. dalmatinskog korpusa Generalštabu Jugoslavenske armije od 25. veljače 1945. o Mostarskoj operaciji, 143-160.

${ }^{32}$ U borbama za Mostar uništena je 369. pukovnija u sastavu 369. pješačke divizije. Ona je raspuštena za vrijeme povlačenja njemačke vojske, a ono što je ostalo od navedene pukovnije raspoređeno je u 370. pukovniju 369. pješačke divizije. Omjer stradanja drugih njemačkih postrojbi navedene divizije nije poznat. F. SCHRAML, Hrvatsko ratište, 106-109.
} 
(hrvatske) pješačke divizije nestali su u ratu. ${ }^{33}$ Ratnu dokumentaciju zapovjedništva IX. hrvatske gorske divizije i njoj podređenih postrojbi NDH-a u Mostaru, sa sjedištem u Liska ulici (danas Ulica kneza Mihajla Viševića Humskog), pokupili su sredinom veljače ustaški časnici koji su se povlačili prema Sarajevu, Brodu na Savi, a negdje u Sesvetama spalili su navedenu dokumentaciju. ${ }^{34}$

Kad je riječ o obavještajnim podatcima Gestapa, njemačke obavještajne službe, nalazimo dijametralno suprotnu stvarnost. Arhiv njemačke obavještajne službe nalazio se u kući, visokoj katnici, na križanju Šetališta i Bakamluka. Njemački časnici koji su pazili na dokumentaciju pobjegli su i ostavili iza sebe arhiv obavještajnih podataka. Pripadnici 29. hercegovačke divizije prodrli su u Mostar 14. i 15. veljače i nakon nekoliko dana spalili su kuću i cjelokupan arhiv njemačke obavještajne službe u Mostaru. ${ }^{35}$

Dijelovi VIII. dalmatinskoga korpusa i 29. hercegovačke divizije 20. veljače 1945. zauzeli su Jablanicu i nastavili potiskivati oružane snage Njemačke i NDH-a. Snage NOVJ-a 1. ožujka osvojile su Ostrožac, 3. ožujka Konjic, a 4. ožujka izbile su na Ivan-sedlo. Zauzimanjem Drežnice 16. veljače završena je Mostarska operacija, dok su osvajanjem Ivan-sedla, kojega je zauzela 29. hercegovačka divizija, okončane borbe za zauzimanje Hercegovine. ${ }^{36}$

Postrojbe VIII. dalmatinskoga korpusa održale su u Mostaru 20. veljače paradu partizanskih postrojbi na kojoj su bili načelnik Glavnoga štaba NOV-a Hrvatske Pavao Jakšić, saveznički časnik i članovi CK KPJ-a Vicko Krstulović i Avdo Humo. Nakon nekoliko dana odmora postrojbe VIII. dalmatinskoga korpusa prebačene su u sjevernu i srednju Dalmaciju na nove zadaće. U Hercegovini je ostala samo 29. hercegovačka divizija koja je, zajedno s 3. brigadom bosanskohercegovačke divizije KNOJ-a, preuzela zadatak uspostave revolucionarne komunističke vlasti prema već ustaljenom receptu obračuna s političkim neistomišljenicima. ${ }^{37}$

${ }^{33}$ Zadnji sačuvani mikrofilm je rola br. 2156 koja obuhvaća razdoblje ljeta 1943. godine. Sjedinjene Američke Države (dalje: SAD), The National Archives, National Archives and Records Service (dalje: NARA), Guides to German records Microfilmed at Alexandria, (dalje: GGRMA), VA. NO. 41. Records of German Field Commands: Division (Part I) (dalje: RGFCD), General Services Administration, Washington, 1964., 179-189.

${ }^{34}$ Mate Tomas služio je kao pismonoša, a i pisar u Stožeru IX. hrvatske gorske divizije. A. ČUVALO, Od Bleiburga do Ljubuškog. Svjedočenja preživjelih, Ljubuški - Chicago, 2014., 370.

${ }^{35}$ BIH-PVPMLPŠB-IKDM, Mostar, 31. ožujka 2009., 72.

${ }^{36}$ HDA-D1182-NOV i PO Hrvatske, VIII. dalmatinski korpus, rola br. 9, sn. 218., 219., 220., 221., 222., 234. i 240. Usp. B. MATKOVIĆ, Zločini postrojba VIII. dalmatinskog korpusa NOVJ-a u Hercegovini početkom 1945. godine, 325.

${ }^{37}$ B. MATKOVIĆ, Zločini postrojba VIII. dalmatinskog korpusa NOVJ-a u Hercegovini početkom 1945. godine, 325-326. 


\section{Teror OZNA-e i KNOJ-a prema hrvatskom stanovništvu u veljači 1945. u Mostaru}

OZNA i KNOJ planski su, provedbom metode razdavanja i likvidacije, počinili niz ubojstava mjesnoga stanovništva u Mostaru. Prema izvješću 3. brigade bosanskohercegovačke divizije KNOJ-a u razdoblju od 29. siječnja do 24. veljače 1945. ubijen je 91, zarobljeno 150 i ranjeno 15 ustaša i škripara od te postrojbe. ${ }^{38}$

U Spomenici Mostara 1941. - 1945. zbog ideoloških razloga žrtve partizanskih zauzimanja Mostara prešućene su ili se jednostavno njima manipuliralo na način da za razlog njihova ubojstva optuže neprijateljsku, odnosno poraženu stranu u ratu. Prema iskazu Ilije Šaravanje postrojbe 12. hercegovačke brigade 14. veljače u Rodoču ovladale su zrakoplovnim uzletištem te pobili 32 civila hrvatske narodnosti. Ubačeni su u rovove koji su služili njemačkoj vojsci za obranu položaja na zrakoplovnoj luci. Šaravanja navodi da je među ubijenima nekoliko njegovih rođaka sa Slipčića, i to: Ivan Bevanda, Pavo Hrapović, »Lazeta, Dogić... « ${ }^{39}$ U području odgovornosti 13. hercegovačke brigade 14. veljače, kad su te partizanske postrojbe potpuno ovladale Bunom, ubijeno je 12 žena i djece hrvatske nacionalnosti. Partizani su žrtvama vezali kamenje o vrat, nakon čega su ih bacili u Neretvu. ${ }^{40}$

Drugi historiografski izvori precizno opisuju što se događalo tih dana, 14. i 15. veljače, za vrijeme borbi u Mostaru. Prema dostupnim iskazima, partizani su, nakon završetka borbe, uhitili Peru Blaževića i ubili ga u Sarajevu nekoliko dana kasnije. ${ }^{41}$ Zatim partizani uhićuju i Iliju Blaževića te ga ubijaju u veljači 1945 . godine. ${ }^{42}$ Također je Marko Cvitanović uhićen 15. veljače pod optužbom da je radio za ustaški pokret. Partizani su ga, prema jednom iskazu, nakon mučenja ubili sredinom svibnja 1945. godine. ${ }^{43}$ Prema istraživanju jednoga poslijeratnoga pripadnika službi si-

\footnotetext{
${ }^{38}$ Rezultat akcija naših jedinica za vrijeme od 29. 1. do 24. 2. 1945., Štab III. Hercegovačke brigade b-h divizije KNOJ, pov. br. 138 od 27. februara 1945. »Mostar «, Republika Srbija (dalje: RS), Vojni arhiv u Beogradu (dalje: VAB), Narodnooslobodilačka vojska Jugoslavije 1941. - 1945. (dalje: fond NOVJ 1941. - 1945.), br. Reg. 26., kut. 222., f16., 1.

${ }^{39}$ HR-HDA-1805-ZPKD, Iskaz Ilije Šaravanje, kut. 2., oznaka f12.6., 1. U zbirci fra Krunoslava Draganovića nisu sačuvana njihova izvorna imena. Usp. B. MATKOVIĆ, Zločini postrojba VIII. dalmatinskog korpusa NOVJ-a u Hercegovini početkom 1945. godine, 323.

${ }^{40}$ HR-HDA-1805-ZPKD, Iskaz Ilije Šaravanje, kut. 2., oznaka f12.6., 1-2. U zbirci fra Krunoslava Draganovića nisu sačuvana njihova izvorna imena. Usp. B. MATKOVIĆ, Zločini postrojba VIII. dalmatinskog korpusa NOVJ-a u Hercegovini početkom 1945. godine, 323.

${ }^{41}$ Bosna i Hercegovina (dalje: BiH) Pismohrana Hrvatskog dokumentacijskog centra Domovinskog rata u Bosni i Hercegovini (dalje: PHDCDRBIH), Politički zatvorenici (dalje: PZ), Mostar, mapa 16, iskaz Brune (Pere) Blaževića, 6.

${ }^{42} \mathrm{BiH}-\mathrm{PHDCDRBIH}-\mathrm{PZ}$, Mostar, mapa 62, iskaz dr. Stjepana Dragoje, 4-5.

${ }^{43}$ BiH-PHDCDRBIH-PZ, Mostar, mapa 36, iskaz Marka (Bože) Cvitanovića, 14.
} 
gurnosti, Cvitanović je ubijen u noći 14 . veljače u Mostaru. ${ }^{44} \mathrm{Na}$ Lučkom mostu u noći s 14. na 15. veljače ubijen je Mehmed Brajlović, a na isti način ubijena je Ilka Jurišin. ${ }^{45}$ Nadalje, tih dana u veljači ubijeni su Ante Lasta $\gg$ Anton $\ll{ }^{46}$ Nikola Rozić, Ivan Fleger, Emin Voloder, Luca Ćorić i Ana Smoljan. ${ }^{47}$

Prema dokumentaciji fonda Političkih zatvorenika za grad Mostar partizani su, bez suđenja, ubili domobranskoga časnika - stomatologa Antu (Augusta) Cipru koji je radio u vojnoj bolnici u Južnom logoru. Nakon ubojstva bačen je u Neretvu 14 . veljače $1945 .^{48}$ Pripadnik oružanih snaga NDH-a Jozo (Ivan) Cvitanović uhićen je 14. veljače 1945. godine. Zajedno s ostalim zarobljenicima odveden je u vojarnu Sjeverni logor. Partizani su ga ubili u ožujku iste godine. ${ }^{49}$ Prema istraživanjima povjesničara Ivice Šarca partizani su 14. i 15. veljače u Mostaru usmrtili Šćepu Miljka, Delmu Komadina (r. Dugandžić), Anđela Arapovića, Stjepana Miljku, Stojana Markića, Ivana Zovka, Nikolu Krtalića, Mladena Bruka i Petra Matića. ${ }^{50} \mathrm{~S}$ druge strane u Spomenici se od ubijenih Hrvata spominju njih trojica: Ivan (Pere) Zovko »Ivko « za kojega se navodi da je poginuo kao pripadnik 2. bataljuna 10. hercegovačke brigade u Ribnici (Slovenija), ${ }^{51}$ za Nikolu (Ivana) Krtalića navodi se da je poginuo od metka 1945. u Jasenici ${ }^{52}$ i za Mladena (Franju) Bruka ističe se da je » poginuo od zalutalog metka 14. februara 1945. u Mostaru $\ll .{ }^{53}$ Nameće se logičan zaključak kako je uređivačko vijeće Spomenice svjesno izostavilo pripadnike NOVJa kao glavne odgovorne za ubojstva dvojice civila Nikole Krtalića i Mladena Bruka, dok je u slučaju Ivana Zovka umetnuto da je ubijen kao pripadnik partizanskoga pokreta, a ne kao civil. Primjeri krivotvorina i insinuacija u navedenoj Spomenici mogli bi se nizati unedogled, pa zauzeti i knjigu, no to bi daleko nadmašilo svrhu i već nadaleko premašenoga prvobitno planiranoga opsega ovoga rada.

\footnotetext{
${ }^{44}$ BiH-PVPMLP-IKDM, Mostar, 30. ožujka 2009., 57.

${ }^{45}$ Isto, 53. i 61.

${ }^{46}$ Ubili su ga pripadnici Mladih muslimana iz Donje Mahale. BiH-PVPMLP-IKDM, Mostar, 30. ožujka 2009., 62.

${ }^{47}$ Isto, 51-64. Usp. I. ŠARAC, Metastaza jedne revolucije, 299-301.

${ }^{48}$ BiH-PHDCDRBIH-PZ, Mostar, mapa 33, iskaz Vlatka (Ante) Cipre, 5-6.

${ }^{49}$ BiH-PHDCDRBIH-PZ, Mostar, mapa 34, iskaz Joze (Ivana) Cvitanovića, 16.

${ }^{50}$ I. ŠARAC, Metastaza jedne revolucije, 306-307.

${ }^{51}$ G. ULJAREVIĆ, N. MILIVOJEVIĆ, R. HAMZIĆ, K. D. MILETIĆ, B. BUHA, Spomenica Mostara 1941. - 1945., 106.

${ }^{52}$ Isto, 235.

${ }^{53}$ Isto, 228.
} 
Po opsegu zločina i svirepim mučenjima nisu zaostajali pripadnici organizacije Mladi muslimani. ${ }^{54}$ Jedan od njihovih istaknutih čelnika bio je politički komesar Hamdija Peco koji je na okrutan način mučio, mrcvario i naposljetku ubijao zarobljene njemačke vojnike u jednom bunkeru u Donjoj Mahali i kod Ančića pećine nad Neretvom. ${ }^{55}$

Očigledno je broj ratnih zločina nakon zauzimanja Mostara bio u porastu, odnosno oteo se nadzoru. Tako se u mjesečnom izvještaju od 16. ožujka komesara 26. dalmatinske divizije potpukovnika Dušana Koraća upućenom komesaru IV. jugoslavenske armije ističe

»drugo pitanje koje su nametnule operacije u zapadnoj Hercegovini, a koje su ranija iskustva pokazala da se ne može računati rešenim a delomično su potvrdile i operacije na Mostaru, jeste odnos boraca prema narodu i njihovoj imovini. Postoji spremnost da se pojam 'neprijateljski raspoloženo stanovništvo' bukvalno shvati, i bez ikakvog laviranja dosledno postupi kao sa takvim. Ovo nas rukovodioce primorava da daleko opreznije prilazimo ovim pitanjima. Na Širokom Brijegu bilo je više i grubljih ispada i njima se moglo progledati kroz prste s obzirom na stvarno raspoloženje naroda, ali je ovo utoliko više otežalo sprečavanje ovakvih pojava u samom Mostaru, gdje je situacija bila drugačija. $\ll^{56}$

Samo jedan mali dio dostupne dokumentacije pruža nam uvid u odnos NOVJ-a prema političkim neistomišljenicima i ratnim zarobljenicima u veljači 1945. godine. Stvarni omjer stradanja hrvatskoga stanovništva u Mostaru i gubitaka oružanih snaga NDH-a nakon završetka borbi za Mostar 15. veljače 1945. nije moguće precizno utvrditi. Pretpostavljalo se da su velik broj likvidacija civila i ratnih zarobljenika u borbama za Mostar i u vrijeme uspostave revolucionarne vlasti na tek osvojenom području počinili pripadnici 2. i 3. bojne 5. brigade narodne obrane 1 . hrvatske divizije KNOJ-a, kao i pripadnici 3. brigade bosanskohercegovačke KNOJ-a za BiH. ${ }^{57}$

${ }^{54}$ BiH-PVPMLP-IKDM, Mostar, 30. ožujka 2009., 62.

${ }^{55}$ Isto, 72.

${ }^{56}$ Mesečni izveštaj političkog komesara 26. udarne divizije od 16. marta 1945. političkom komesaru 4. armije JA o partijsko-političkom i kulturno-prosvetnom radu u diviziji. ZNOR, IX/9., dok. 31., $151-158$.

${ }^{57}$ Ubijeno 40 i zarobljeno 20 neprijateljskih vojnika. Bataljun je imao 7 poginulih i 45 ranjenih. HRHDAST-1912-XXVI. dalmatinska divizija, Operativno izvješće od 13. siječnja do 12. veljače 1945. Štaba 3. bataljuna 11. dalmatinske brigade upućeno Štabu 11. dalmatinske brigade, original u Vojno-istorijskom institutu JNA, reg. br. 2-2/11, kut. 1101., kutija 7., 2., HR-HDAST-1912-XXVI. dalmatinska divizija, V. brigada narodne obrane I. hrvatske divizije KNOJ-a, Operativni dnevnik 2. bataljuna KNOJ-a, kutija 7. Original u Vojno-istorijskom institutu JNA, reg. 1-27/13, br. 1101 , HR-HDAST-1912-XXVI. dalmatinska divizija, V. brigada narodne obrane I. hrvatske divizije 


\section{TERor OZNA-E I KNOJ-A PREMA hrVATSKIM ZarobLJENICIMA KRIŽNOGA PUTA U SVIBNJU I LIPNJU U MOSTARU}

U razdoblju od svibnja do kolovoza 1945. Mostar je bio jedan od postaja križnoga puta, a daljnje postaje prostirale su se do istočne Hercegovine, Crne Gore, Srbije i Makedonije. ${ }^{58}$ Partizani su u Mostaru organizirali niz logora, zatvora i vojnih sudova za obračun s političkim neistomišljenicima. Jedan od takvih logora bila je vojarna Zapadni logor u Mostaru. ${ }^{59}$ OZNA i KNOJ tim su se mjestom, odnosno Biskupovom glavicom, lokalitetom pored same vojarne, koristili nakon 15. veljače 1945. kao poligonom za smaknuća onih zarobljenika koji su dovedeni u vojarnu Zapadni logor. Riječ je o privođenju hrvatskih ratnih zarobljenika s Križnoga puta u zatvoru Ćelovini. Dio zarobljenika ubijen je i bačen u jamu na kojoj je kasnije izgrađeno partizansko groblje, odnosno spomenik ispod kojega se nalaze većim dijelom posmrtni ostatci poginulih njemačkih vojnika i pripadnika oružanih snaga $\mathrm{NDH}-\mathrm{a} .{ }^{60}$ Vojna oblast 29. hercegovačke divizije aktom br. 515/45 od 4. ožujka 1945. mijenja dosadašnji naziv Odjeljenje zaštite naroda Odjeljenja za $\mathrm{BiH}$ u Odjeljenje zaštite narod za oblast Hercegovine. Nadalje, dosadašnje sekcije Odsjeka dobivaju naziv Odsjeci odjeljenja, a rukovoditelji sekcija dobivaju naziv šefovi odsjeka. ${ }^{61}$

Poraženim pripadnicima oružanih snaga NDH-a, hrvatskim zarobljenicima i mjesnom pučanstvu sudili su sudci Srbi i Muslimani. Sud je kao svjedoke pozivao Srbe i Muslimane iz rodnih sela osuđenika, a njihov kredibilitet bio je upitan. Poznata su mjesta i kuće gdje su se prije svjedočenja sastajali svjedoci te usuglašavali svoje iskaze. Rodbina suđenika najčešće nije ni znala za suđenje pa nije ni bilo prigode

KNOJ-a, Operativni dnevnik 3. bataljuna KNOJ-a, original u Vojno-istorijskom institutu JNA, reg. 1-21/14, br. 1101., kutija 7., 72. i HR-HDAST-1912-XXVI. dalmatinska divizija, Predmet izvješća 3. bataljuna 11. dalmatinske brigade u napadu na Mostaru 12. ožujka 1945., original u Vojno-istorijskom institutu JNA, reg. br. 4-11, k. 1101., kutija 7., 1.

${ }^{58}$ M. G. RAVANČIĆ, Bleiburg i Križni put 1945. Historiografija, publicistika i memoarska literatura, Zagreb, 155-160.

${ }^{59} \mathrm{Na}$ tom mjestu izgrađeno je partizansko groblje u Mostaru 1965., na mjestu nekadašnje vojarne Zapadni logor, koja se nalazila na prostoru današnjega stadiona NK-a Zrinski i Sveučilišta u Mostaru na padinama Bijeloga Brijega. Po idejnom rješenju beogradskoga arhitekta Bogdana Bogdanovića groblje ima 661 nadgrobni kamen, simbolična značenja, ispod kojih nisu posmrtni ostatci partizana, kako se ranije tvrdilo, nego prikriva pristup masovnim grobnicama koje su dokaz strahovite komunističke odmazde. Jedan od ciljeva bilo je prikrivanje masovnih grobnica nastalih nakon 15. veljače 1945. na tom mjestu. H. MANDIĆ, Na partizanskom groblju u Mostaru pokopani su njemački vojnici i vojnici NDH. Dostupno na: http://www.hrsvijet.net/index.php/vijesti/24herceg-bosna/49453-hrvoje-mandic-na-partizanskom-groblju-u-mostaru-pokopani-su-njemackivojnici-i-vojnici-ndh-video (13. 12.2018.).

${ }^{60}$ V. MABIĆ, Od Širokog do Bleiburga i nazad, Široki Brijeg, 2017., 237-238. i 509-510.

${ }^{61}$ RS-VAB-NOVJ 1941. - 1945., br. Reg. 43., kut. 1740., f. 3., 1. 
za obranu i vjerodostojne svjedoke. Osuđenici na smrt vojnoga suda 29. hercegovačke divizije ubijeni su u gradu ili na stratištima oko Mostara. Teško je utvrditi koliki je broj ubijenih Hrvata na montiranim sudskim procesima u režiji KPJ-a. U izvješću Komisije za utvrđivanje ratnih i poratnih žrtava detaljniji podatci navode se samo za jedno mostarsko grobište, i to tzv. jamu kod Bijeloga polja u koju su 9. srpnja 1945. bačena 153 zarobljenika iz Ćelovine. Na jednom od takvih montiranih sudskih procesa osuđen je 15. lipnja 1945. umirovljeni svećenik iz Stoca don Ivan Raguž na smrt strijeljanjem. ${ }^{62}$

Prema zbirci preslika Krunoslava Draganovića u jami Varduša od Ljubinja prema Stocu ubijeno je i ubačeno oko 7000 vojnika koji su dovođeni u kolonama iz Mostara. Masovna ubojstva činjena su pod zapovjedništvom kapetana OZNA-e Deana Čapine iz Domanovića. ${ }^{63}$ Prema iskazu Ilije Šaravanje križari su u prosincu 1945. likvidirali Deana Čapinu u svatovima u selu Kruševu. OZNA je za odmazdu uhitila 19 civila iz Kruševa i okolnih sela za Božić i navodno su ih poubijali na istom mjestu gdje je ubijen kapetan Dean Čapina. Među ubijenima su navodno Andrija Čule, dva brata Bobankića, Rozić i Ćulušić. ${ }^{64}$

U Čapljini na crkvenoj livadi pored velike crkve nalazi se masovna grobnica u kojoj je pokopano oko 200 muškaraca, žena, djece i staraca. Navodno su ondje pokopane četiri časne sestre i fra Andrija Jelčić. Prema drugim izvorima ondje je pokopana jedna časna sestra i fra Petar Sesar. ${ }^{65}$ Prema nekim drugim saznanjima fra Petar Sesar ubijen je i bačen u masovnu grobnicu na Radimlji. ${ }^{66}$ Zatim, iz smjera Čapljine prema Mogorjelu, kod mjesta Brista nalazi se također masovna grobnica ${ }^{67}$

Veći dio hrvatskih zarobljenika transportiran je vlakovima i kamionima prema trebinjsko-bilećko-nikšićkim jamama i drugim stratištima. Jednu skupinu zarobljeni-

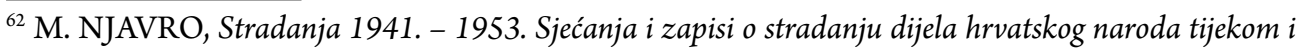
nakon Drugog svjetskog rata u jugoistočnoj Hercegovini i u izbjeglištvu po hrvatskim prostorima, Zagreb, 1998., 201-203. I. PULJIĆ, S. VUKOREP i Đ. BENDER, Stradanje Hrvata tijekom Drugog svjetskog rata i poraća u istočnoj Hercegovini, u: I. PULJIĆ, S. VUKOREP (ur.), Humski zbornik, 59. Usp. B. MATKOVIĆ, Poslijeratni komunistički zločini i grobišta u istočnoj Hercegovini, u: Hum, časopis Filozofskog fakulteta Sveučilišta u Mostaru 9(2012.)9, 208.

${ }^{63}$ HR-HDA-1805-ZPKD, Izvješće Hrvatskog pokreta otpora u Trstu pri Zapovjedništvu V. Zbora Hrvatskih oružanih snaga, kut. 4., f. 36.2., 4.

${ }^{64}$ HR-HDA-1805-ZPKD, Iskaz Ilije Šaravanje, kut. 2., f12.6., 2.

${ }^{65}$ Razgovor s fra Miljenkom Stojićem, vicepostulatorom postupka mučeništva u Širokom Brijegu 20. kolovoza 2018. u 15 sati.

${ }^{66}$ Dostupno na: http://pobijeni.info/fratri/fra-petar-sesar/ (29.10. 2019.).

${ }^{67}$ HR-HDA-1805-ZPKD, Izvješće Hrvatskog pokreta otpora u Trstu pri Zapovjedništvu V. Zbora Hrvatskih oružanih snaga, kur. 4., f. 36.2., 4. 
ka oružanih snaga NDH partizani su transportirali prema Nevesinju. Oni koji nisu stigli do tog odredišta ubijeni su i bačeni u jami Novakuša u Bišini koju su nevesinjske i mostarske poratne vlasti pretvorile u odlagalište smeća kako bi prekrili ratni zločin. Prema iskazima partizana navodno su u Podveležju ubijani zarobljeni domobrani i bačeni u škripove. ${ }^{68}$

Prema dostupnim historiografskim izvorima u jedan je transport iz zatvora Ćelovina u Mostaru ukrcano 600 zatvorenika. Iz jedne od kolona kojom je iz Sarajeva stiglo u Mostar 740 zarobljenika izdvojeno je u Mostaru samo njih 16 rođenih 1925. godine, dok su ostali odvezeni dalje. Kada je u Mostar stigla osječka kolona s 370 zarobljenika, izdvojeno je tek 7 mladića mlađih godišta, a ostali su također proslijeđeni u smjeru Trebinja. Poznanici i rodbina budno su pratili prolaz vlakova, kao i Hrvati koji su bili zaposleni na željeznici. Svjedok Ivan Raubic potkraj 1945. navodi kako je vidio kraj Trebišnjice 200 do 300 zarobljenih domobrana koji su vadili iz vode dijelove porušenoga mosta te u vagone, koji su odlazili prema Crnoj Gori, tovarili raznu robu. Vjerovali su da će nakon završetka posla biti pušteni kućama, no nisu se vratili domovima. Kasnije je u Vinkovcima Raubic upoznao Franju Matića, lovočuvara rodom iz Hercegovine, koji je bio pripadnik 29. hercegovačke divizije, a poslije KNOJ-a. Po vlastitome svjedočenju Matić je kao pripadnik KNOJ-a čuvao domobrane koje je vidio Raubic, a koji su nakon završetka posla pobijeni u njemačkim rovovima na Bradini. Osim toga Raubicu je ispričao i kako su domobrani koji su u Podveležju sjekli šumu također pobijeni i bačeni u škripove po Veležu. ${ }^{69}$

Prema istraživanjima fra Krunoslava Draganovića od sredine svibnja do kraja srpnja 1945. partizani su ubili 306 pripadnika oružanih snaga NDH-a iz Hercegovine na nepoznatim mjestima. ${ }^{70}$ Dostupni dokument postrojbi 3. divizije KNOJ-a navodi da su u vremenu od 1. siječnja 1945. do 1. listopada 1946. ubili 6466 ustaša, četnika, domobrana Nijemaca, jataka, ratnih zarobljenika, švercera, dezertera, špijuna i zelenokadrovaca te ranili $791 .^{71}$ Prema istraživanjima povjesničarke Blanke Matković, jedna od najvećih masovnih grobnica pobijenih s Bleiburga i križnoga

${ }^{68}$ I. PULJIĆ, S. VUKOREP, Đ. BENDER, Stradanje Hrvata tijekom Drugog svjetskog rata i poraća u istočnoj Hercegovini, 60. Usp. B. MATKOVIĆ, Poslijeratni komunistički zločini i grobišta u istočnoj Hercegovini, 209-211. i M. NJAVRO, Stradanja 1941. - 1953., 115-123., 177-180.

${ }^{69}$ M. NJAVRO, Stradanja 1941. - 1953., 115-123., 177-180., I. PULJIĆ, S. VUKOREP, Đ. BENDER, Stradanje Hrvata tijekom Drugog svjetskog rata i poraća u istočnoj Hercegovini, 60-62. Usp. B. MATKOVIĆ, Poslijeratni komunistički zločini i grobišta u istočnoj Hercegovini, 209-211.

${ }^{70}$ HR-HDA-1805-ZPKD, Izvješće Hrvatskog pokreta otpora u Trstu pri Zapovjedništvu V. Zbora Hrvatskih oružanih snaga, kut. 4., f. 36.2., 5-10.

71 >Pregled postignutih rezultata i vlastitih gubitaka jedinica 3. b-h divizije KNOJ-a u vremenu od 1. januara 1945. do 1. oktobra 1946.«RS-VAB-NOVJ 1941. - 1945., br. Reg. 9-1, kut. 222., f. 8., 1. 
puta nalazi se u Hercegovini, na lokalitetu Radimlja kod Stoca. Lokalitet Radimlja sastoji se od četiriju ili pet jama gdje su partizani nakon Bleiburga i križnoga puta počinili masovna ubojstva. Prema procjenama na spomenutom lokalitetu ubijeno je u poraću 1864 vojnika i civila iz istočne Hercegovine, ali i drugih mjesta. ${ }^{72} \mathrm{Kad}$ je riječ o hrvatskom civilnom stanovništvu i vojnicima oružanih snaga NDH-a iz Mostara, zasad je nemoguće utvrditi precizan broj ubijenih u veljači i neposrednom poraću 1945. godine.

\section{Zaključna razmatranja}

Postrojbe VIII. dalmatinskoga korpusa zauzele su 15. veljače 1945. Mostar i time uspostavile kontrolu nad donjim tokom rijeke Neretve. Štab navedenoga korpusa nije uspio okružiti Mostar i uništiti oružane snage Njemačke i NDH-a koje su branile taj grad i neposredno pred početak borbi za Mostar glavninu svojih snaga povukli su prema Konjicu i dalje prema Sarajevu. Zauzimanjem Drežnice 16. veljače završena je Mostarska operacija, dok su borbe za zauzimanje Hercegovine okončane 4. ožujka, kada je 29. hercegovačka divizija osvojila Ivan-sedlo. Partizani su zauzimanjem Mostara počinili niz zločina prema hrvatskom civilnom stanovništvu u Mostaru. Dosadašnja jugoslavenska historiografija ciljano je zanemarila popisati neke stradale hrvatske civile zauzimanjem Mostara u Spomenici Mostara, ali isto tako one popisane hrvatske civile svjesno je prešutjela krijući pravi uzrok njihove smrti. U Hercegovini je ostala samo 29. hercegovačka divizija koja je, zajedno s 3. brigadom bosanskohercegovačke divizije KNOJ-a, preuzela zadatak uspostave revolucionarne komunističke vlasti prema već ustaljenom receptu obračuna s političkim neistomišljenicima. U razdoblju od svibnja do kolovoza 1945. Mostar je bio jedan od postaja Križnoga puta, a daljnje postaje prostirale su se do istočne Hercegovine, Crne Gore, Srbije i Makedonije. Partizani su u Mostaru organizirali niz logora, zatvora i vojnih sudova za obračun s političkim neistomišljenicima. Jedan od takvih logora bila je vojarna Zapadni logor u Mostaru. OZNA i KNOJ tim mjestom, odnosno Biskupovom glavicom, lokalitetom pored same vojarne, koristili su se nakon 15. veljače 1945. kao poligonom za smaknuća onih zarobljenika koji su dovedeni u vojarnu Zapadni logor. Riječ je o privođenju hrvatskih ratnih zarobljenika s križnoga puta u zatvoru Ćelovini. Dio zarobljenika ubijen je i bačen u jamu na kojoj je kasnije izgrađeno partizansko groblje, odnosno spomenik ispod kojega se nalaze većim dijelom posmrtni ostatci poginulih njemačkih vojnika i pripadnika oružanih snaga NDH-a. Dio zarobljenika oružanih snaga NDH-a partizani su transportirali prema Nevesinju. Oni koji nisu stigli do toga odredišta ubijeni su i bačeni u jamu Novakuša u Bišini. Veći dio hrvatskih zarobljenika prevezen je vlakovima i

${ }^{72}$ B. MATKOVIĆ, Poslijeratni komunistički zločini i grobišta u istočnoj Hercegovini, 215. 
kamionima prema trebinjsko-bilećko-nikšićkim jamama i drugim stratištima. Prema iskazima partizana navodno su u Podveležju ubijani zarobljeni domobrani i bačeni u škripove. Zasad nije moguće precizno utvrditi broj ubijenih hrvatskih civila i vojnika oružanih snaga NDH-a iz Mostara u veljači i neposrednom ratnom poraću 1945. godine. 
THE RELATIONSHIP OF NOVJ TOWARDS THE CROATIAN CIVILIANS AND THE DEFEATED SOLDIERS OF THE NDH ARMED FORCES IN MOSTAR AT THE END OF WORLD WAR II AND THE IMMEDIATE AFTERMATH

\author{
Hrvoje MANDIĆ*
}

Summary: By seizing Mostar, the Yugoslav National Liberation Army (NOVJ) established control over the lower course of the Neretva River and achieved one of two preconditions for establishing a revolutionary communist government in the area. The second precondition was dealing with all potential political opponents in Mostar. The problem of the suffering of the Croatian population in February and the immediate aftermath of 1945 in Mostar has not been sufficiently investigated. The Communist authorities deliberately neglected the Croatian civilian casualties in February and the aftermath of 1945 with the help of regime historiography. The paper is a contribution to the research on the Croatian victims in Mostar. The paper uses descriptions, historical-narrative method, content analysis method, counting/enumeration method, and oral history method. By implementing the method of division and liquidation, the Department for People's Protection (OZNA) and the People's Defence Corps of Yugoslavia (KNOJ) committed a systematic series of murders of Croatian civilians and members of the Independent State of Croatia's (NDH) armed forces in Mostar, in February and the immediate aftermath of 1945. The largest execution sites of murdered civilians and soldiers are located under the partisan monument in Mostar, in the Novakuša Cave towards Nevesinje, and the Radimlja site near Stolac.

Keywords: Mostar, Josip Broz Tito, Independent State of Croatia's (NDH) armed forces, NOVJ, OZNA, KNOJ, Partisan monument.

\footnotetext{
* Hrvoje Mandić, Ph. D., Central Office for the Archive of the University in Zagreb, Ulica kralja Zvonimira 8, 10000 Zagreb, Croatia, hrmandic@gmail.com
} 